\title{
Response of emergent macrophytes to hydrological changes in a shallow lake, with special reference to nutrient cycling
}

\author{
A. E. Lawniczak $\cdot$ J. Zbierska $\cdot$ A. Choiński $\cdot$ \\ W. Szczepaniak
}

Published online: 8 September 2010

(C) The Author(s) 2010. This article is published with open access at Springerlink.com

\begin{abstract}
The effect of water level reduction on nutrient concentrations and productivity of emergent macrophytes was analyzed in a shallow, polymictic lake, located in Central-Western Poland. The water level was regulated for irrigation purposes from 1974 to 2002 , with an average amplitude of $0.85 \mathrm{~m}$. In 2002, the water level was reduced by $0.60 \mathrm{~m}$ during winter time and by $0.40 \mathrm{~m}$ in summer time. Nutrient concentrations, nitrogen, phosphorus, and potassium standing stocks and aboveground biomass production
\end{abstract}

Guest editors: A. Pieterse, S. Hellsten, J. Newman, J. Caffrey, F. Ecke, T. Ferreira, B. Gopal, J. Haury, G. Janauer,

T. Kairesalo, A. Kanninen, K. Karttunen, J. Sarvala,

K. Szoszkiewicz, H. Toivonen, L. Triest, P. Uotila, N. Willby /

Aquatic Invasions and Relation to Environmental Changes:

Proceedings of the 12th International Symposium on Aquatic

Weeds, European Weed Research Society

A. E. Lawniczak $(\bowtie) \cdot$ J. Zbierska

Department of Ecology and Environmental Protection, Poznan University of Life Sciences, ul. Piatkowska 94 C, 60-649 Poznan, Poland

e-mail: lawnic@up.poznan.pl

\section{A. Choiński}

Institute of Physical Geography and Environmental

Planning, Adam Mickiewicz University,

ul. Dziegielowa 27, 61-680 Poznan, Poland

\section{W. Szczepaniak}

Department of Agricultural Chemistry and Environmental Biogeochemistry, Poznan University of Life Sciences, ul. Wojska Polskiego 71E, 60-625 Poznan, Poland were compared among four vegetation types along with a moisture gradient in the littoral zone. This study was conducted in the littoral zone of Lake Niepruszewskie during the growing seasons in 1999-2001 (1st period with high water level) and 2005-2008 (2nd period with low water level). The reduction of water level resulted in a negative effect on biomass production and nutrient concentrations. Stoichiometric indexes, like $\mathrm{N}: \mathrm{P}$ and $\mathrm{N}: \mathrm{K}$ ratios, indicate that the shift in nutrient limitation due to changes in hydrological conditions caused a reduction of the nutrient uptake by vegetation and affected productivity. The decrease in the aboveground biomass production was more marked at sites that were less affected by drainage, i.e., permanently flooded. However, in drawdown areas, plant growth decreased. Species including Phragmites australis and Carex acutiformis coped better with the reduction of water levels than Typha angustifolia and Glyceria maxima.

Keywords Water level reduction - Littoral . Macrophytes · Productivity · Nutrient concentrations

\section{Introduction}

Littoral zones can play a role as buffer zones located at the interface of the terrestrial and aquatic environment and are valued for their capacity to remove nitrate, phosphate, or potassium from lake ecosystems (Van Donk et al., 1993), particularly from 
sediments as well as from agricultural runoff (Jansson et al., 1998). Littoral zones can be described as nutrient-rich systems with very high productivity and rapid nutrient cycling (Gopal \& Masing, 1990; Coops et al., 1999), strongly affected by water level fluctuations, their duration, frequency, rate of filling and drying, timing or wave exposure (Scheffer, 1998; Casanova \& Brock, 2000). In eutrophic ecosystems, this zone is mostly created by emergent macrophytes which can uptake large quantities of phosphorus and nitrogen as well as potassium from the sediments via their root systems (Carignan \& Kalff, 1980).

Shallow lake ecosystems are most sensitive to hydrological changes since even small changes may significantly influence nutrient cycles and macrophyte distribution and biodiversity (Casanova \& Brock, 2000; Seabloom \& van der Valk, 2003; Egertson et al., 2004). Furthermore, even small changes in frequency of floods and their duration may significantly influence biochemistry of the littoral zone, and trigger changes in species composition, which may, for example, suppress rare species or promote invasive ones (Van den Brink, 1994; Van Geest et al., 2003), change the uptake of nutrients by plant species, and increase or decrease demineralization and denitrification processes (Kallner Bastviken et al., 2007). Water level directly influences plant traits, for example, increased water depth may cause elongation of culms and increased shoot:root ratios, increase the proportion of aerenchymatous tissue in shoots and roots, or induce the formation of adventitious roots (Steinmann \& Brändle, 1984; Armstrong et al., 1991, 1994). It indirectly affects plants through changes in sediment characteristics, nutrient availability, water transparency, and wind or wave exposure (Weisner, 1991; Scheffer, 1998). Wetland plant species are characterized by high adaptability to water level changes. However, species composition and their productivity vary between sites and depend also, for example, on morphology of water bodies, eutrophication or acidification, and recreational activities (Murphy, 2002). Niche differentiation contributes to zonal distribution of emergent macrophytes in water bodies, and their coexistence can be determined by tolerance to drought and flooding (Smith \& Brock, 1996).

Knowledge about responses of individual species to hydrological conditions may enable more efficient restoration or promote ecologically sensitive hydrological management. On the other hand, it is also necessary for restoration purposes to maintain the proper water level regime as a key factor regulating the functioning and expansion of littoral emergent vegetation (Coops et al., 2004).

Long-term data are essential to understand the trajectory of changes in macrophyte communities and their ability to take up nutrients, particularly in water bodies exposed to human pressures (Hellsten et al., 1996; Egertson et al., 2004). Macrophytes are excellent indicators of the ecological state of water bodies, mainly because they integrate environmental changes over periods of a few years, and reflect the cumulative effects of successive disturbances (Tremp \& Kohler, 1995). Most studies have, however, analyzed the effects of water level fluctuations in short term or in experimental conditions (Coops et al., 1996; Casanova \& Brock, 2000; Deegan et al., 2007). However, in the longer term, plants may either adapt to the new hydrological conditions or disappear. Therefore, it is necessary to consider macrophyte responses from a longer term perspective in order to correctly identify the relative impacts of hydrological change on nutrient cycling and other processes.

In the Wielkopolska region, where this study was conducted, many water bodies are degraded by elevated nutrient and sediment loadings, mostly from the agricultural watershed (Zbierska et al., 2002; Lawniczak et al., 2008). The majority of lakes are highly eutrophic and dominated by emergent vegetation. The development of submerged aquatic macrophytes is constrained by low light penetration caused by phytoplankton shading (Lawniczak, 2006). In recent decades, decreased water levels, as well as their fluctuations and late stages of vegetation succession, have been observed in many lakes (Choiński, 2006). However, the effect and consequences of these changes on shallow, very eutrophic lakes, particularly on development of different species in the littoral zone, remain poorly understood.

The specific objectives of the study were: first, to determine if the pattern of change in the aboveground biomass of four emergent macrophytes was affected by reduction of water level over a 10 -year period (1999-2008); second, to assess if the standing stocks and tissue concentrations of nitrate $(\mathrm{N})$, phosphorus $(\mathrm{P})$, and potassium $(\mathrm{K})$ changed in response to the new hydrological regime; and, third, how stoichiometric indexes of $\mathrm{N}: \mathrm{P}$ and $\mathrm{N}: \mathrm{K}$ ratios reflect changes of nutrient limitations in the littoral zone. 


\section{Methods}

Site description

Lake Niepruszewskie is situated in the Central-Western part of Poland $\left(52^{\circ} 22.700^{\prime} \mathrm{N}, 16^{\circ} 37.200^{\prime} \mathrm{E}\right)$, about $25 \mathrm{~km}$ west of the city of Poznan. This freshwater postglacial lake is highly elongated, with the average depth of $2.9 \mathrm{~m}$, maximum $4.8 \mathrm{~m}$ (Lawniczak \& Choiński, unpublished data). This is the first in a series of lakes connected via the Samica Steszewska River. The water level was regulated at its outlet by a weir, for irrigation purposes, from 1974 to 2002 with average annual amplitude of $0.85 \pm 0.24 \mathrm{~m}$ (Fig. 1). During 1999-2002, minimum water level was observed at the level of $76.40 \mathrm{~m}$ a.s.l. and maximum at $77.52 \mathrm{~m}$ a.s.1., while the lake surface area varied between 260 and 281 ha. The highest levels were measured during winter and early spring (average $77.05 \pm 0.26 \mathrm{~m}$ a.s.1.), the lowest during autumn (average $76.71 \pm 0.16 \mathrm{~m}$ a.s.l.).

In 2002, the water level was reduced due to the suspension of the water supply consent and due to pressure from landowners who have allotments located near the lake. A new maximum water level of $76.90 \mathrm{~m}$ a.s.1. during winter months (I-III), and the maximum of $76.70 \mathrm{~m}$ a.s.1. and minimum of $76.40 \mathrm{~m}$ a.s.l. during the rest of the year (IV-XII) were established. Since 2003 water level has been significantly reduced by $0.60 \mathrm{~m}$ during winter time, and by $0.40 \mathrm{~m}$ in summer time $(F=36, P<0.0001)$. The lowest water level of $76.06 \mathrm{~m}$ a.s.l. was observed in 2003 resulting from the combined effect of the imposed reduction of water level and very low precipitation and high temperatures during the summer of that year (Fig. 1). At the present time, the highest water levels still occur during early spring time (76.50 $\pm 0.12 \mathrm{~m}$ a.s.1.) after the snow melt, and mostly due to management for fisheries, to favor fish reproduction. During this period, average annual amplitude of water level was $0.47 \pm 0.12 \mathrm{~m}$, with average water level of $76.85 \mathrm{~m}$ a.s.l. Still, the lowest water level was observed during autumn (76.25 \pm $0.12 \mathrm{~m}$ a.s.l.), and the highest during winter and early spring (76.50 $\pm 0.12 \mathrm{~m}$ a.s.l.).

Field procedure

Sampling sites were selected in eight different parts of the naturally developed littoral zone of Lake Niepruszewskie. At each sampling area, at least two plots of $1 \mathrm{~m}^{2}$ were selected with different types of communities, resulting from different moisture conditions. One plot of each 8 was situated in the periodically flooded part of the littoral zone (approximately $2 / 3$ width of the littoral zone from the shoreline), the second one of each 8 -in the seasonally drier area located closer to the shoreline (approximately 1/3 width of the littoral zone from the shoreline). In addition, six plots were established in the second, seasonally drier site, characterized by higher biodiversity. All plots were marked permanently with plastic sticks and strips. Sampling sites were selected within the following dominant plant communities: Phragmitetum australis, Typhetum angustifoliae, Caricetum acutiformis, and Glycerietum
Fig. 1 Water level fluctuation in Lake Niepruszewskie from March 1999 to December 2008

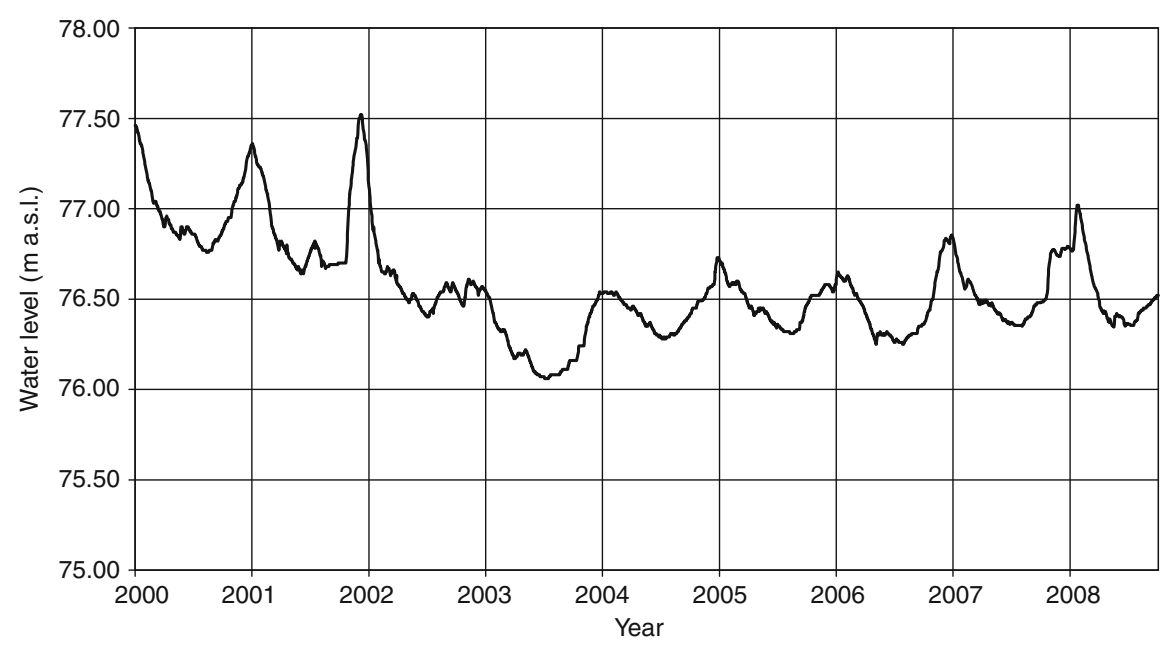


maximum. In total, 22 plots were selected. Each plot consisted of three subplots.

This study was carried out in the littoral zone of Lake Niepruszewskie during two periods: first-with high water level, covering three growing seasons in 1999-2001; and, secondly-with reduced water level in years 2005-2006 and 2008. The water level in the lake was measured daily during 1999-2008.

The aboveground biomass of littoral vegetation at each community type was measured by harvesting at ground level four randomly placed subplots (each $50 \times 50 \mathrm{~cm}$ ) within each strip. Assessments were undertaken at maximal shoot growth in August of each year. The plants were washed carefully in tap water to clean them of periphyton.

\section{Laboratory procedure}

The plant samples were sorted according to species into living and dead fractions, dried for $48 \mathrm{~h}$ at $70^{\circ} \mathrm{C}$ and weighed. The weights were converted into biomass per square meter. For further nutrient determinations, the ground biomass of dominant helophytes: Phragmites australis (Cav.) Trin. ex Steud. (Common reed), Typha angustifolia (L.) (Lesser Reedmace), Carex acutiformis L. (Lesser pond sedge), and Glyceria maxima (C. Hartm.) Holmb. (Reed Sweet Grass), was digested with a Kjedahl procedure (Bremner \& Mulvaney, 1982). The $\mathrm{N}$ and $\mathrm{P}$ concentrations of the diluted digested material were determined colorimetrically on a Srecord 40, and the $\mathrm{K}$ concentration with flame emission spectroscopy, on a Shewood Model 425.

\section{Statistical analyses}

All statistical analyses were performed using Statistica (StatSoft, Poland) software. The data were transformed (square root or logarithmic) to assess the homogeneity of variance. Effects of three- and two-way interactions of sampling year, species, and location in the littoral zone on shoot biomass were tested with analyses of variance (ANOVA). The significance of the differences between the biomass production and nutrient concentrations within the study sites and periods (1999-2001 and 2005-2006 and 2008) was assessed statistically using ANOVA and a posteriori Tukey's test.

\section{Results}

Impact of reduction of water level fluctuations on shoot biomass

Changes in water level significantly influenced all variables used to describe plant growth (Tables 1,2), particularly production of the aboveground biomass

Table 1 Results of the three-way ANOVA testing of the effects of the time and site on aboveground biomass production, nitrogen, phosphorus, and potassium concentrations

\begin{tabular}{|c|c|c|c|c|c|c|c|c|c|}
\hline \multirow[t]{2}{*}{ Source } & \multirow[t]{2}{*}{ df } & \multicolumn{2}{|c|}{ Shoot biomass $\left(\mathrm{g} \mathrm{dm} \mathrm{m}^{-2}\right)$} & \multicolumn{2}{|c|}{$\mathrm{N}$ con. $\left(\mathrm{mg} \mathrm{g}^{-1}\right)$} & \multicolumn{2}{|c|}{$\mathrm{P}$ con. $\left(\mathrm{mg} \mathrm{g}^{-1}\right)$} & \multicolumn{2}{|c|}{$\mathrm{K}$ con. $\left(\mathrm{mg} \mathrm{g}^{-1}\right)$} \\
\hline & & $F$ & Sig. & $F$ & Sig. & $F$ & Sig. & $F$ & Sig. \\
\hline Species & 4 & 13.76 & 0.000 & 22.49 & 0.000 & 11.29 & 0.000 & 3.86 & 0.010 \\
\hline Site & 1 & 8.52 & 0.004 & 8.72 & 0.003 & 3.79 & 0.053 & 2.07 & 0.152 \\
\hline Period & 1 & 19.13 & 0.000 & 1.49 & 0.224 & 42.39 & 0.000 & 75.36 & 0.000 \\
\hline Year & 5 & 28.87 & 0.000 & 1.33 & 0.254 & 34.22 & 0.000 & 21.74 & 0.000 \\
\hline Species $\times$ period & 4 & 7.26 & 0.000 & 0.35 & 0.786 & 0.73 & 0.538 & 3.12 & $\mathbf{0 . 0 2 7}$ \\
\hline Site $\times$ period & 1 & 0.02 & 0.892 & 0.28 & 0.601 & 0.42 & 0.517 & 0.19 & 0.662 \\
\hline Species $\times$ year & 16 & 3.46 & 0.000 & 1.90 & 0.025 & 2.83 & 0.000 & 2.21 & 0.007 \\
\hline Species $\times$ site & 2 & 5.10 & 0.007 & 0.87 & 0.353 & 1.61 & 0.206 & 0.04 & 0.844 \\
\hline Year $\times$ site & 5 & 2.38 & 0.039 & 4.17 & 0.001 & 1.79 & 0.117 & 0.69 & 0.633 \\
\hline Species $\times$ year $\times$ site & 2 & 0.82 & 0.443 & 1.28 & 0.281 & 1.30 & 0.275 & 0.19 & 0.831 \\
\hline
\end{tabular}

Biomass and $\mathrm{P}$ concentrations were ln-transformed, and $\mathrm{N}$ and $\mathrm{K}$ concentrations square-rooted. Data are $F$-ratios and significance levels given as *** $P<0.001$ (bold); ** $P<0.01$ (bold); $* P<0.05$ (bold); and ns, $P \geq 0.05$. The time effect included years and two periods - first with high amplitude of water levels (1999-2001), second with reduction of water level fluctuations (2005-2008) 
Table 2 Results of the three-way ANOVA testing of the effects of the time and site on nitrogen (N), phosphorus (P), and potassium (K) standing stocks

\begin{tabular}{|c|c|c|c|c|c|c|c|}
\hline \multirow[t]{2}{*}{ Source } & \multirow[t]{2}{*}{ df } & \multicolumn{2}{|c|}{ 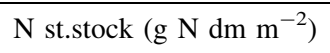 } & \multicolumn{2}{|c|}{ 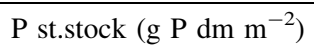 } & \multicolumn{2}{|c|}{$\mathrm{K}$ st.stock $\left(\mathrm{g} \mathrm{K} \mathrm{dm} \mathrm{m}^{-2}\right)$} \\
\hline & & $F$ & Sig. & $F$ & Sig. & $F$ & Sig. \\
\hline Species & 4 & 20.44 & 0.000 & 8.83 & 0.000 & 4.38 & 0.002 \\
\hline Site & 1 & 36.30 & 0.000 & 54.18 & 0.000 & 40.59 & 0.000 \\
\hline Period & 1 & 25.20 & 0.000 & 53.44 & 0.000 & 49.11 & 0.000 \\
\hline Year & 5 & 1.88 & 0.172 & 4.27 & 0.040 & 0.30 & 0.581 \\
\hline Species $\times$ period & 4 & 11.19 & 0.000 & 7.36 & 0.000 & 8.47 & 0.000 \\
\hline Site $\times$ period & 1 & 0.48 & 0.488 & 0.23 & 0.629 & 0.95 & 0.332 \\
\hline Species $\times$ year & 16 & 2.59 & 0.077 & 4.61 & 0.011 & 0.82 & 0.443 \\
\hline Species $\times$ site & 2 & 5.18 & 0.000 & 3.92 & 0.000 & 4.03 & 0.000 \\
\hline Year $\times$ site & 5 & 3.37 & 0.006 & 1.84 & 0.106 & 4.04 & 0.002 \\
\hline Species $\times$ year $\times$ site & 2 & 0.86 & 0.427 & 1.00 & 0.369 & 0.06 & 0.938 \\
\hline
\end{tabular}

$\mathrm{N}$ and $\mathrm{P}$ in standing stocks were $\mathrm{ln}$-transformed, and $\mathrm{K}$ in standing stocks was square-rooted. Data are $F$-ratios and significance levels given as *** $P<0.001$ (bold); ** $P<0.01$ (bold); * $P<0.05$ (bold); and ns, $P \geq 0.05$. The time effect included years and two periods - first with high amplitude of water levels (1999-2001), second with reduction of water level fluctuations (2005-2008)

of the macrophytes (Fig. 2) and tissue nutrient concentrations (Fig. 3). All growth variables also differed significantly among the plant species; interspecific differences were stronger than the site effect for both shoot biomass and nutrient standing stocks. Two-way interactions between time or site effects and species were sometimes significant but always much weaker than the main effects (Tables 1,2), indicating that the effects of the hydrological changes were essentially consistent across species but not across sites.

The shoot biomass production in the littoral zone during the period of reduced water level (2005-2008) was significantly lower than the biomass production during the period of higher water levels (1999-2001) (ANOVA, $F=7.261, P<0.001$; Table 1 ). The Phragmitetum australis and Typhetum angustifoliae showed a significantly higher productivity compared to the other communities. The aboveground biomass of $P$. australis and T. angustifolia varied approximately 1.4- and 2-fold, respectively, across the analyzed years, with minimal values in 2008 (886 g dry matter $\mathrm{m}^{-2}$ ) and maximal values in 1999-2001 (2,480 $\mathrm{g} \mathrm{dm} \mathrm{m}^{-2}$, Fig. 2). Significant changes occurred in Typhetum angustifoliae and Glycerietum maximae communities, with biomass decreasing by $58 \%$ and $40 \%$ during analyzed periods. At the dryer site, located close to the shoreline (site 2), the growth of Caricetum acutiformis showed different patterns to other assemblages. An

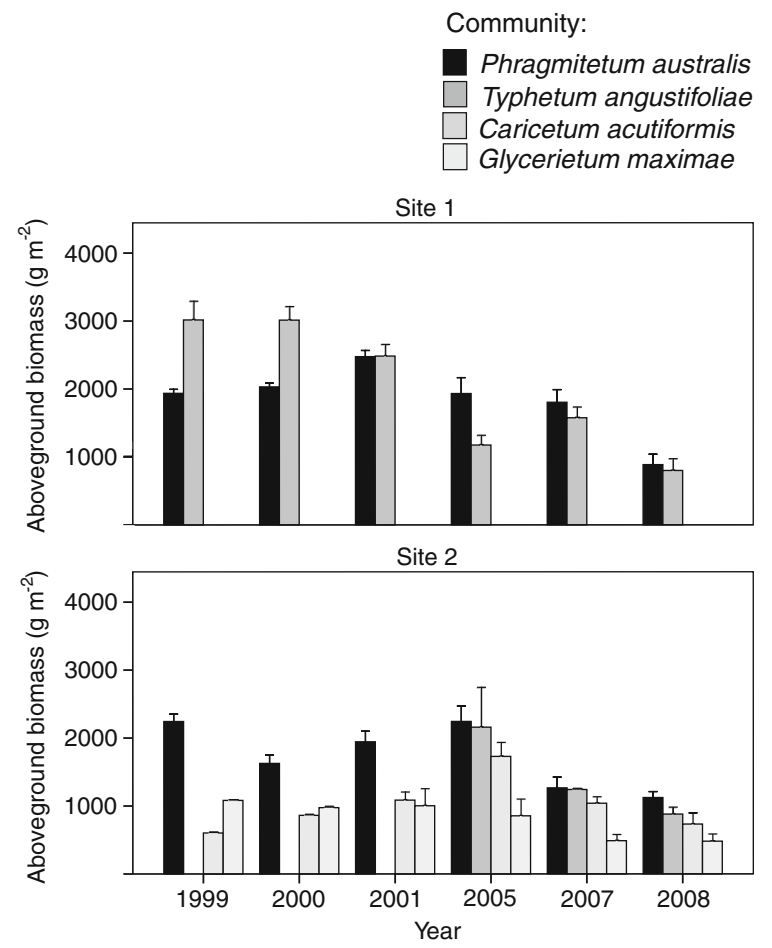

Fig. 2 Mean $( \pm \mathrm{SE})$ living aboveground biomass $\left(\mathrm{g} \mathrm{m}^{-2}\right)$ of four dominant communities in August 1999-2008 at two sites (1-periodically wet, 2-seasonally dry)

increase of biomass production was observed not only during 1999-2001 but also in 2005. The highest biomass of C. acutiformis recorded in 2005 was 
(a)

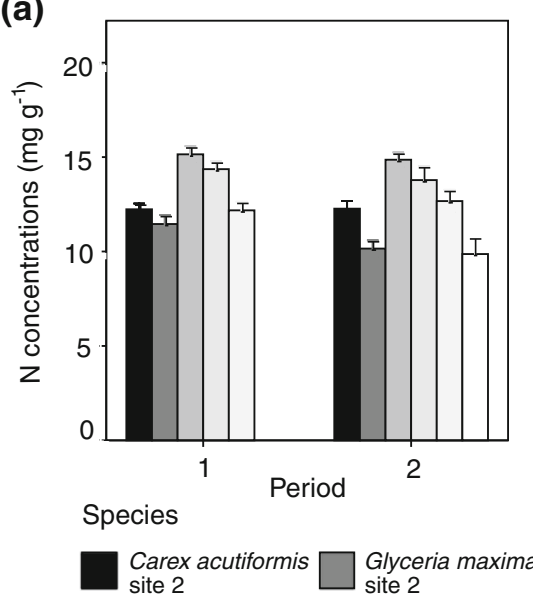

(b)

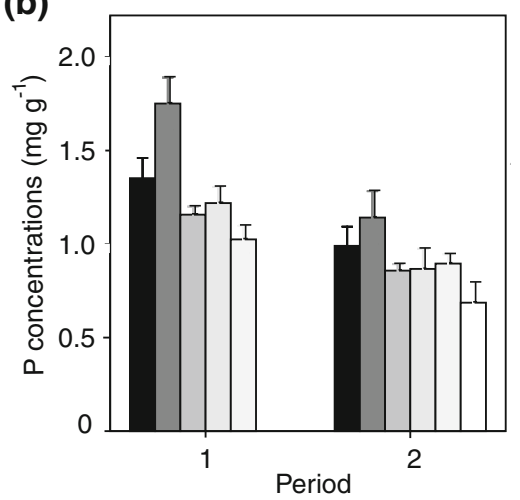

Period (c)

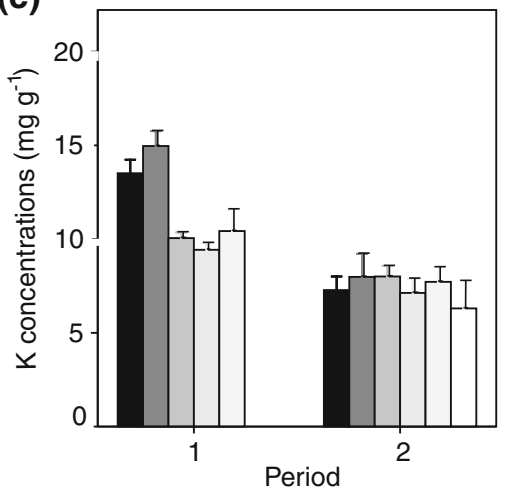

Fig. 3 Mean $( \pm \mathrm{SE})$ a $\mathrm{N}$ concentrations $\left(\mathrm{mg} \mathrm{g}^{-1}\right)$, b $\mathrm{P}$ concentrations $\left(\mathrm{mg} \mathrm{g}^{-1}\right)$, and $\mathbf{c} \mathrm{K}$ concentrations $\left(\mathrm{mg} \mathrm{g}^{-1}\right)$ in the living aboveground biomass of helophytes at two sites (1-periodically wet, 2-seasonally dry) in period with high water level (1), and period with low water level (2)

throughout the studied years (Table 1; Fig. 3b, c). The highest concentrations of both nutrients were observed during higher water levels, particularly in the species which grew in the seasonally flooded part of the littoral zone. The highest average $\mathrm{P}$ and $\mathrm{K}$ concentrations were observed in Glyceria maxima (1.75 $\mathrm{mg} \mathrm{P} \mathrm{g}^{-1}, 14.97 \mathrm{mg} \mathrm{K} \mathrm{g}^{-1}$ ) and the lowest-in Typha angustifolia $\left(10.03 \mathrm{mg} \mathrm{P} \mathrm{g}^{-1}\right)$ and Phragmites australis $\left(9.43 \mathrm{mg} \mathrm{K} \mathrm{g}^{-1}\right)$. Significant differences in $\mathrm{P}$ and $\mathrm{K}$ concentrations in shoot plant tissue, with the exception of T. angustifolia, were found between two analyzed periods (Table 1).

The N:P and $\mathrm{N}: \mathrm{K}$ ratios varied during the analyzed periods within helophytes (Fig. 4a, b). Similar patterns of the stoichiometric indexes were observed for almost all species. After drawdown in April 2002 and continuously sub-sediment water levels, a decrease of $\mathrm{K}$ concentrations was observed and, consequently, values of $\mathrm{N}: \mathrm{K}$ ratios increased, being significantly higher in 2005-2008 than in 1999-2001 (Fig. 4b). The median of $\mathrm{N}: \mathrm{K}$ ratios of the macrophytes varied from 1.4 to 1.9 at sites which were periodically flooded and from 1.2 to 1.8 at seasonally flooded sites. The same pattern was observed in N:P ratios for all species. However, an increase of N:P was noted since 2000, before the reduction of water level. The most significant rise was still noted during the second analyzed period. The median of N:P ratios of the macrophytes varied from 13.7 to 16.3 at periodically flooded sites and from 11.2 to 15.6 at seasonally drier sites. 
Fig. 4 Mean a N:P concentrations and $\mathbf{b} \mathrm{N}: \mathrm{K}$ concentrations in helophytes at two sites (1-periodically wet, 2 - seasonally dry) in 1999-2008 (1999-2001period with high water level, 2005-2008-period with low water level) (a)

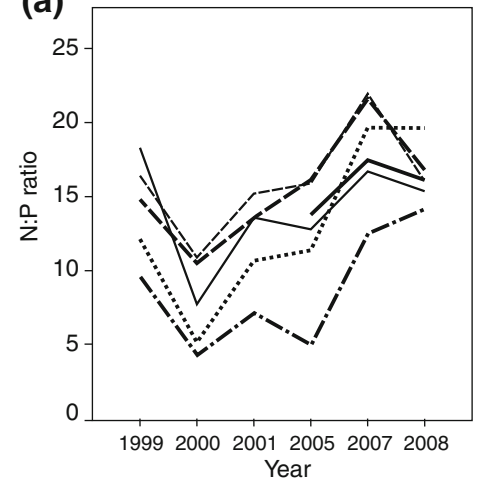

(b)

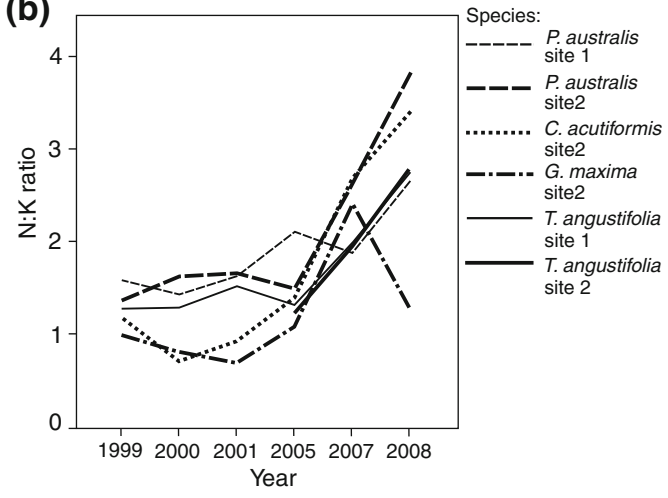

\section{Species}

Phragmites australis Typha angustifolia $\square$ Carex acutiformis Glyceria maxima

Site 1

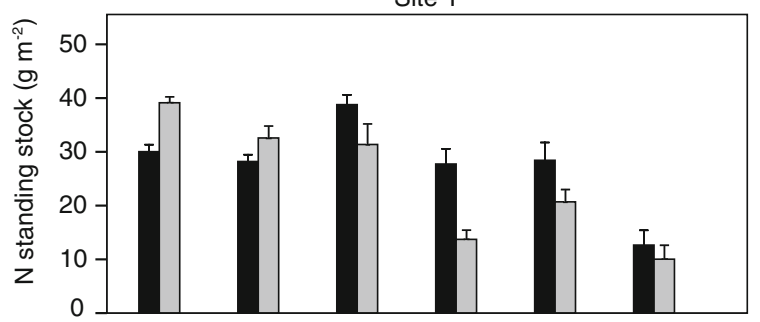

Site 2

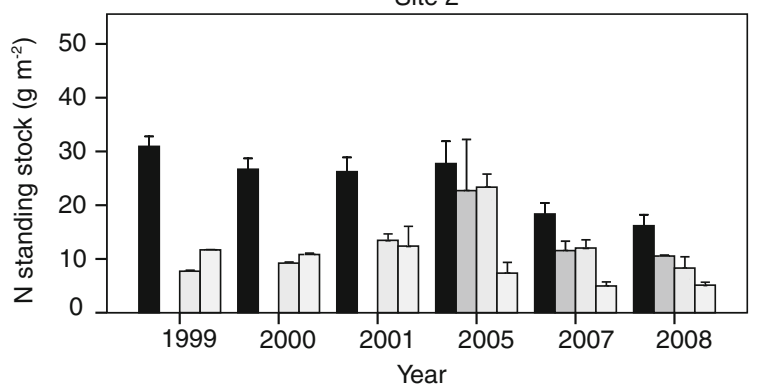

Fig. 5 Mean $( \pm \mathrm{SE}) \mathrm{N}$ standing stock $\left(\mathrm{g} \mathrm{m}^{-2}\right)$ in the living aboveground biomass of helophytes at two sites (1-periodically wet, 2-seasonally dry) in 1999-2008 (1999-2001period with high water level, 2005-2008-period with low water level)

Effect of water level changes on nutrient standing stock

Changes in nitrogen standing stock (Table 2; Fig. 5) were directly related to shoot biomass. During years with higher amplitude of water level, statistically higher values were observed in all species, except for C. acutiformis. The biggest changes were noted in

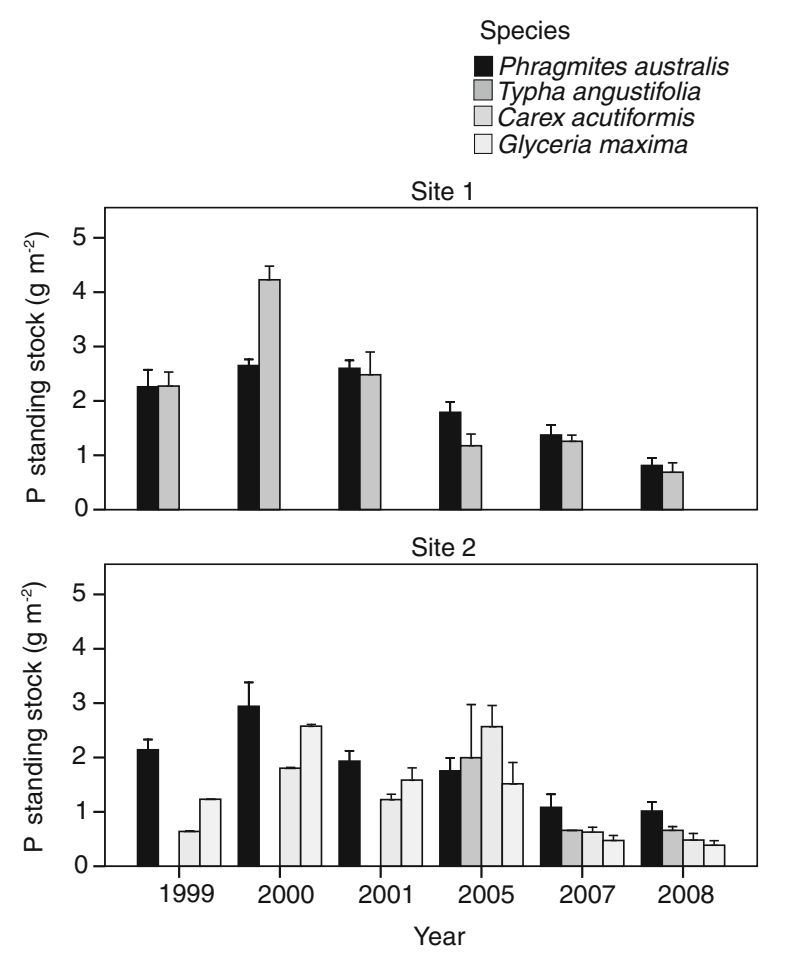

Fig. 6 Mean $( \pm S E) P$ standing stock $\left(\mathrm{g} \mathrm{m}^{-2}\right)$ in the living aboveground biomass of helophytes at two sites (1-periodically wet, 2-seasonally dry) in 1999-2008 (1999-2001period with high water level, 2005-2008-period with low water level)

Typha angustifolia whose nutrient standing stock decreased by $56 \%$ of $\mathrm{N}, 64 \%$ of $\mathrm{P}$, and $70 \%$ of $\mathrm{K}$ standing stocks (Figs. 5, 6, 7). The smallest differences occurred in Phragmites australis at both sites, in which nitrogen standing stock decreased, on average, by $41 \%$ of $\mathrm{N}, 44 \%$ of $\mathrm{P}$, and $37 \%$ of $\mathrm{K}$; differences between these two sites were not statistically significant. 


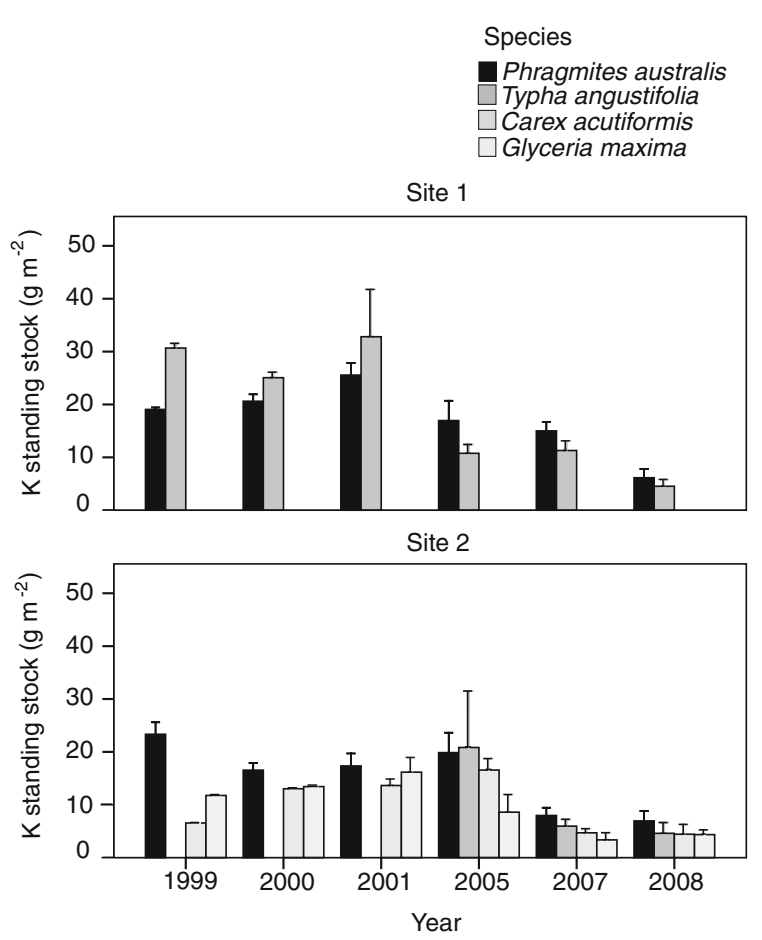

Fig. 7 Mean $\left( \pm\right.$ SE) $\mathrm{K}$ standing stock $\left(\mathrm{g} \mathrm{m}^{-2}\right)$ in the living aboveground biomass of helophytes at two sites (1-periodically wet, 2-seasonally dry) in 1999-2008 (1999-2001period with high water level, 2005-2008-period with low water level)

Only for $C$. acutiformis increased standing stock by $45 \%$ of $\mathrm{N}$ and $37 \%$ of $\mathrm{P}$ and decreased by $11 \%$ of $\mathrm{K}$ between the two studied periods was detected. However, variations in $\mathrm{K}$ standing stock between the two periods in sedges were not statistically significant. The highest nutrient standing stock in C. acutiformis was measured in 2005, and this was the highest average nutrient storage of all plant species during the period with low water level.

\section{Discussion}

This study sought to determine the effects of water level reduction (WLR) on biomass production and nutrient concentrations in the emergent macrophytes in the natural littoral zone of a shallow lake. Our results clearly indicate that changes in water level have significant influence on helophyte productivity. The reduction of water level caused lower production of the aboveground biomass in all of the analyzed communities. Shoot biomass of the studied macrophytes ranged approximately from 481 to $3016 \mathrm{~g} \mathrm{~m}^{-2}$, which was in the middle range of peak shoot biomass observed in macrophytes for eutrophic, natural, or constructed wetlands; treatment wetlands; and marshes (Gopal \& Masing, 1990; Toet et al., 2005).

The highest, negative response to the reduction of water level was observed in Typhetum angustifoliae and Glycerietum maximae communities, whose shoot biomass decreased by approximately $58 \%$ and $40 \%$, respectively. The most sensitive to water stress was the Glycerietum maximae community which did not cope well with drier conditions. In Lake Niepruszewskie, the shallow part was dominated by Caricetum acutiformis, and small patches were covered by Glycerietum maximae communities. Stands of Glyceria maxima and Carex acutiformis expanded only into relatively shallow water, with a maximum water depth of 30 and $55 \mathrm{~cm}$, respectively. Therefore, these assemblages were more exposed to drier conditions. However, a significant decrease of biomass production was observed mostly in Glycerietum maximae community. In contrast, the growth of Carex acutiformis did not reduce immediately after moderate reduction of water level. A decrease of sedge biomass production was scarcely observed after 3 years of WLR. Delayed reaction of sedges to water level changes, when compared to other analyzed helophytes, was also observed in the lakes in northern Sweden (Sjöberg \& Danell, 1983). Moreover, even between studied patches with Carex species, differences of productivity were significant. A decrease in standing crop and shoot densities was observed immediately in first year of flooding only in one of the lakes. In the other ones, the response of plant species to water increase was slower and significant in longer time. This response also varied between studied lakes indicating that the tolerance of particular species to diverse water conditions depends also on other factors.

The moisture gradient in the lake determined zonal distribution of plant species composition and influenced nutrient uptake (Spence, 1982; Coops, 1996; Lawniczak, 2006). However, changes in water level also caused changes in species distributions. The observed stage of the succession had a linear direction from land to the open water, with gradual replacement of species according to their preferences. Phragmites australis showed an intermediate range, with an average water depth of $35 \mathrm{~cm}(\max .75 \mathrm{~cm})$, 
while $T$. angustifolia was generally found in deeper water than the other above-mentioned three species (average 60 and maximum $130 \mathrm{~cm}$ water depth). A high capacity for rhizosphere oxidation by Typha species allows growth in deeper water (Armstrong et al., 1991, 1994) in comparison with the other studied species and, therefore, made it easier for this species to extend over deeper parts of the littoral zone (Coops, 1996). However, in Niepruszewskie Lake, Typha was gradually replaced by Phragmites, which is a much stronger competitor than other species, and benefited most from the reduced water depth. At the site seasonally dry, disappearance of Typha was observed. The reduction in water level caused expansion of Phragmites in the direction of the open water, thus common reeds became the most dominant species in the lake. The findings for $P$. australis are consistent with a survey carried out by Engloner (2009) who found that this species could accommodate both static and fluctuating water levels. However, our study showed that moderate changes in water levels also significantly influenced reed productivity.

These results correspond with the study of Vretare et al. (2001) who found that P. australis performs better in static than in fluctuating water, and its growth is inhibited by ca. $25 \%$ when grown in fluctuating water levels with the amplitude of about $25 \mathrm{~cm}$. In contrast, several studies confirm that shoot density of $P$. australis is higher in flooded conditions (Coops, 1996; Weihe \& Neely, 1997) which indicates a gradual enhancement of reed biomass production in perennially wet conditions. However, the decrease of common reed productivity at the seasonally drier site may have occurred not only directly due to water level changes but also indirectly via the competition for light which may limit photosynthetic capacity. Drier sites become more available for seed dispersal and germination and that may promote growth of different terrestrial species (Buttery \& Lambert, 1965; Coops \& Velde, 1995). At the site located closer to the shoreline, most of the studied patches were covered by Calystegia sepium the density of whose leaves effectively limited the growth of reed and the development of other species. This probably resulted in lower aboveground biomass productivity of Phragmites after the water level reduction.

Reduction of Glyceria maxima biomass can be explained by its suppression by Phragmites. Moreover, Buttery \& Lambert (1965) stressed that differences between these two species in their habits and seasonal patterns of growth seem to be partly independent of competition effects but, on the other hand, due to its morphological adaptation Glyceria can benefit from the competition with Phragmites. Glyceria starts to grow early in the year and creates shallow rhizomes which produce a series of new shoots throughout the growing season, while Phragmites starts its growth in late spring and produces rhizomes persistent and deepseated. Thus, rapid production of dense swards in early spring may suppress growth of reeds. However, this pattern was not observed in the studied littoral zone which may suggest that Phragmites was either more tolerant to habitat conditions unfavorable to both species (Buttery \& Lambert, 1965) or that the reduction of water levels caused changes of nutrient availability in the soil (Sollie et al., 2007). The second hypothesis is supported by the results of nutrient concentrations in tissues of Glyceria indicating that modifications in nutrient availability in the littoral zone occurred due to the reduction of water level.

Quite consistent patterns were observed regarding the effect of WLR on phosphorus and potassium concentrations in plant tissue. Nitrogen concentrations in plants did not show any significant differences in relation to changes in hydrological conditions. This suggests that the reduction in water level did not influence nitrogen uptake by plants; however, concentrations of $\mathrm{N}$ in the plant tissue indicate limitation of $\mathrm{N}$, particularly in Glyceria maxima. The $\mathrm{N}$ concentrations of $\mathrm{G}$. maxima were lower than 13-14 mg/g, which indicates that the growth was limited by N (De Wit et al., 1963). However, in well-drained sites the release of $\mathrm{N}$ through mineralization should increase the rate of $\mathrm{P}$ limitation (Roem \& Berendse, 2000), but in floodplains and open water swamps $\mathrm{N}$ limitation of vegetation is widespread (Willby et al., 2001). N limitation in Glyceria patches could have occurred due to the loss of mobile $\mathrm{N}$ from plant litter via leaching, mineralization or denitrification (Willby et al., 2001). Also $\mathrm{P}$ and $\mathrm{K}$ concentrations were relatively low in the tested species, particularly after reduction of water level, and were below corresponding "critical $\mathrm{P}$ and $\mathrm{K}$ concentration" of $0.7 \mathrm{mg} / \mathrm{g}$ (Wassen et al., 1995) and $8 \mathrm{mg} / \mathrm{g}$ (De Wit et al., 1963), respectively.

Clearly the shift in nutrient limitation, which was observed in Lake Niepruszewskie due to changes of 
water depth, was reflected in the stoichiometric indices of $\mathrm{N}: \mathrm{P}$ and $\mathrm{N}: \mathrm{K}$ ratios. The plant $\mathrm{N}: \mathrm{P}$ or $\mathrm{N}: \mathrm{K}$ ratios more precisely reflected the gradual and dynamic character of nutrient limitation and shifts in nutrient availability than separately analyzed nutrient concentrations (N-limited vs. P-limited or K-limited) as demonstrated by Koerselman \& Meuleman (1996) and Güsewell \& Koerselman (2002). Güsewell \& Koerselman (2002) proposed that the ratio of $\mathrm{N}: \mathrm{P}<14$ indicates $\mathrm{N}$ limitation and that $>16 \mathrm{P}$ limitation, while ratios between $<14 \mathrm{~N}: \mathrm{P}<16$ indicate co-limitation of these nutrients. Hoosbeek et al. (2002) suggested that the value of $\mathrm{N}: \mathrm{K}<1.2$ indicates that the $\mathrm{N}$-limited growth and $\mathrm{K}$-limited growth occur if $\mathrm{N}: \mathrm{K}>1.4$. However, there is still quite considerable disagreement about the "critical $\mathrm{N}: \mathrm{K}$ ratio" above which biomass production is limited (Hoosbeek et al., 2002; Lawniczak et al., 2009). In Lake Niepruszewskie, the observed variations in $\mathrm{N}$ and $\mathrm{P}$ concentrations in plants were quite high but the relationships between nutrient concentrations, particularly $\mathrm{N}: \mathrm{P}$ and $\mathrm{N}: \mathrm{K}$, showed similar patterns between the analyzed species throughout the studied years. The median of $\mathrm{N}: \mathrm{P}$ ratio suggests that a shift from $\mathrm{N}$ limitation to slightly more pronounced $\mathrm{P}$ limitation occurred due to the reduction in water levels. Also changes in $\mathrm{N}: \mathrm{K}$ ratios indicated a shift from $\mathrm{N}-\mathrm{K}$ limitations at sites which were periodically flooded, and $\mathrm{N}$ limitations at seasonally flooded sites, to strong $\mathrm{K}$ limitations at both sites. Decreased $\mathrm{P}$ and $\mathrm{K}$ concentrations were more restricted to the drainage and rewettening sites (Roem \& Berendse, 2000; Van Duren \& Pegtel, 2000; Watts, 2000), which can explain the shortage of these nutrients in the littoral zone.

Changes in the aboveground biomass production and nutrient concentrations in plant tissue account for the total nutrient standing stock. The annual $\mathrm{N}$ storage varied between 5 and $39 \mathrm{~g} \mathrm{~m}^{-2}$ and the $\mathrm{P}$ storage between 0.39 and $4.23 \mathrm{~g} \mathrm{~m}^{-2}$. Moreover, the highest concentrations of nutrients in standing stocks were observed during higher water levels, and these concentrations were high in comparison with other studies (Meuleman et al., 2002; Van der Wygaert et al., 2003). Our results show different responses of wetland species to water depth, which contradicts the results shown by Sollie \& Verhoeven (2007) who found no differences between nutrient concentrations and standing stock in reeds under different water level treatments. This indicates differential sensitivity of macrophytes to changes in the hydrological regime.

\section{Conclusions}

Our results indicate that Glyceria maxima and Typha angustifolia are less tolerant than Phragmites australis and Carex acutiformis of reduced water level. Increased duration of the lower water levels below the sediment surface exerted a negative influence on nutrient uptake of dominant macrophytes. The decrease in aboveground biomass production following hydrological change was more marked at sites periodically flooded, i.e., where water was previously present throughout the year. This study showed the importance of water level changes, particularly on biomass and phosphorus and potassium concentrations in plant tissue. Even small reduction of water level by $0.6 \mathrm{~m}$ during winter and by $0.40 \mathrm{~m}$ during summer changed the development of vegetation and its potential for uptake of nutrients from the sediment and water. In a shallow highly eutrophic lake, the littoral zone plays a crucial role in nutrient cycling which is important for the restoration process. From a lake restoration perspective water levels should therefore be managed to optimize the contribution of vegetation to nutrient cycling.

Acknowledgments The authors would like to thank Hugh Dawson for review of the manuscript and linguistic improvements. The authors are also grateful to students from the Environmental Protection Faculty, Poznan University of Life Sciences, for help during field work. This research was supported by Grants contract number No. N N305 055234 from the Ministry of Science and Higher Education (study carried out in 2008), number 2 P06S 026 28-from the Ministry of Science and Information (for data collected in 2005-2006), and funded by the Poznan University of Life Sciences (data collected from 1999 to 2001).

Open Access This article is distributed under the terms of the Creative Commons Attribution Noncommercial License which permits any noncommercial use, distribution, and reproduction in any medium, provided the original author(s) and source are credited.

\section{References}

Armstrong, W., J. Armstrong, P. M. Beckett \& S. H. F. W. Justin, 1991. Convective gas-flows in wetland plant aeration. In Jackson, M. B., D. D. Davies \& H. Lambers 
(eds), Plant Life Under Oxygen Deprivation. SPA, The Hague, The Netherlands: 283-302.

Armstrong, W., R. Brändle \& M. B. Jackson, 1994. Mechanisms of flood tolerance in plants. Acta Botanica Neerlandica 43: 307-358.

Bremner, J. M. \& C. S. Mulvaney, 1982. Nitrogen - Total. In Page, A. L. (ed.), Methods of Soil Analysis, Part 2. Chemical and Microbiological Properties. American Society of Agronomy, Madison: 595-624.

Buttery, B. R. \& J. M. Lambert, 1965. Competition between Glyceria maxima and Phragmites communis in the region of Surlingham Broad. I. The competition mechanism. Journal of Ecology 53: 18-163.

Carignan, R. \& J. Kalff, 1980. Phosphorus sources for aquatic weeds: water or sediments? Science 207: 987-989.

Casanova, M. T. \& M. A. Brock, 2000. How do depth, duration and frequency of flooding influence the establishment of wetland plant communities? Plant Ecology 147: 237-250.

Choiński, A., 2006. Atlas of Polish Lakes (in Polish). Adam Mickiewicz University Press, Poznan, Poland.

Coops, H., 1996. Helophyte zonation - impact of water depth and wave exposure. $\mathrm{PhD}$ Thesis. Catholic Univerisy Nijmegen, The Netherlands.

Coops, H. \& G. Velde, 1995. Seed dispersal, germination and seedling growth of six helophyte species in relation to water-level zonation. Freshwater Biology 34: 13-20.

Coops, H., F. W. B. van den Brink \& G. van der Velde, 1996. Growth and morphological responses of four helophyte species in an experimental water-depth gradient. Aquatic Botany 54: 11-24.

Coops, H., J. Hanganu, M. Tudor \& W. Oosterberg, 1999. Classification of Danube Delta lakes based on aquatic vegetation and turbidity. Hydrobiologia 415: 187-191.

Coops, H., J. T. Vulink \& E. H. van Nes, 2004. Managed water levels and the expansion of emergent vegetation along a lakeshore. Limnologica 34: 57-64.

De Wit, C. T., W. Dijkshoorn \& J. G. Noggle, 1963. Ionic Balance and Growth of Plants. Verslagen Van Landbouwkundige Onderzoeken, Wageningen.

Deegan, B. M., S. D. White \& G. G. Ganf, 2007. The influence of water level fluctuation on the growth of four emergent macrophyte species. Aquatic Botany 86: 309-315.

Egertson, Ch., J. A. Kopaska \& J. A. Downing, 2004. A century of change in macrophyte abundance and composition in response to agricultural eutrophication. Hydrobiologia 524: $145-156$.

Engloner, A. I., 2009. Structure, growth, dynamics and biomass of reed (Phragmites australis) - a review. Flora 204: 331-346.

Gopal, B. \& V. Masing, 1990. Biology and ecology. In Patten, B. C. (ed.), Wetlands and Shallow Continental Water Bodies. SPB Academic Publishing, The Hague: 91-239.

Güsewell, S. \& W. Koerselman, 2002. Variation in nitrogen and phosphorus concentrations of wetland plants. Perspectives in Ecology, Evolution and Systematics 5: 37-61.

Hellsten, S., M. Marttunen, R. Palomäki, J. Riihimäki \& E. Alasaarela, 1996. Towards an ecologically based regulation practice in Finnish hydroelectric lakes. Regulated Rivers: Research and Management 12: 535-545.

Hoosbeek, M. R., N. Van Breemen, H. Vasander, A. Buttler \& F. Berendse, 2002. Potassium limits potential growth of bog vegetation under elevated atmospheric $\mathrm{CO}_{2}$ and $\mathrm{N}$ deposition. Global Change Biology 8: 1130-1138.

Jansson, A., C. Folke \& S. Langaas, 1998. Quantifying the nitrogen retention capacity of natural wetlands in the large-scale drainage basin of the Baltic Sea. Landscape Ecology 13: 249-262.

Kallner Bastviken, S., P. G. Eriksson, A. Ekström \& K. Konderski, 2007. Seasonal denitrification potential in wetland sediments with organic matter from different plant species. Water, Air, and Soil Pollution 183: 25-35.

Koerselman, W. \& A. F. M. Meuleman, 1996. The vegetation $\mathrm{N}$ : P ratio: a new tool to detect the nature of nutrient limitation. Journal Applied Ecology 33: 1441-1450.

Lawniczak, A. E., 2006. Floristic diversity of the littoral zone communities in Lake Niepruszewskie (in Polish). Poznanskie Towarzystwo Przyjaciol Nauk 100: 113-122.

Lawniczak, A. E., J. Zbierska \& J. Kupiec, 2008. Changes of nutrient concentrations in water sensitive to nitrate pollution from agricultural sources in the Samica Stęszewska River catchment. Annals of Warsaw University of Life Sciences, Land Reclamation 40: 15-25.

Lawniczak, A. E., S. Güsewell \& J. T. A. Verhoeven, 2009. Effect of $\mathrm{N}: \mathrm{K}$ supply ratios on the performance of three grass species from herbaceous wetlands. Basic and Applied Ecology (in press).

Meuleman, A. F. M., R. van Logtestijn, G. B. J. Rijs \& J. T. A. Verhoeven, 2002. Water and mass budgets of a verticalflow constructed wetland used for wastewater treatment. Ecological Engineering 20: 31-44.

Murphy, K. J., 2002. Plant communities and plant diversity in softwater lakes of northern Europe. Aquatic Botany 73: 287-324.

Roem, W. J. \& F. Berendse, 2000. Soil acidity and nutrient supply ratio as possible factors determining changes in plant species diversity in grassland and heathland communities. Biological Conservation 92: 151-161.

Scheffer, M., 1998. Ecology of Shallow Lakes. Chapman and Hall, London, UK.

Seabloom, E. W. \& A. J. van der Valk, 2003. Plant diversity, composition, and invasion of restored and natural prairie pothole wetlands: implications for restorations. Wetlands 23: $1-12$.

Sjöberg, K. \& K. Danell, 1983. Effects of permanent flooding on Carex-Equisetum wetlands in Northern Sweden. Aquatic Botany 15: 275-286.

Smith, R. G. B. \& M. A. Brock, 1996. Coexistence of Juncus articulatus L. and Glyceria australis C.E. Hubb. in a temporary shallow wetland in Australia. Hydrobiologia/ Dev Hydrobiologia 340: 147-151.

Sollie, S. \& J. T. A. Verhoeven, 2007. Nutrient cycling and retention along a littoral gradient in a Dutch shallow lake in relation to water level regime. In Sollie, S. (ed.), Littoral Zones in Shallow Lakes. Contribution to Water Quality in Relation to Water Level Regime. $\mathrm{PhD}$ thesis, Utrecht University, Faculty of Science, Utrecht: 53-68.

Sollie, S., H. Coops \& J. T. A. Verhoeven, 2007. Natural and constructed littoral zones as nutrient traps in eutrophicated shallow lakes. In Sollie, S. (ed.), Littoral Zones in Shallow Lakes. Contribution to Water Quality in Relation to Water 
Level Regime. PhD thesis, Utrecht University, Faculty of Science, Utrecht: 17-32.

Spence, D. H. N., 1982. The zonation of plants in freshwater lakes. Advanced Ecological Research 12: 37-125.

Steinmann, F. \& R. Brändle, 1984. Carbohydrate and protein metabolism in the rhizomes of Scirpus lacustris L. Aquatic Botany 19: 53-63.

Toet, S., M. Bouwman, A. Cevaal \& J. T. A. Verhoeven, 2005. Nutrient removal through shoot harvest of Phragmites australis and Typha latifolia in relation to nutrient loading in a wetland used for polishing sewage treatment plant effluent. Journal of Environmental Science and Health 40: 1133-1156.

Tremp, H. \& A. Kohler, 1995. The usefulness of macrophyte monitoring-systems, exemplified on eutrophication and acidification of running waters. Acta Botanica Gallica 142: 541-550.

Van den Brink, F. W. B., 1994. Impact of hydrology on floodplain lake ecosystems along the Lower Rhine and Meuse. Ph.D thesis, University of Nijmegen, The Netherlands.

Van der Wygaert, I. J. J., L. D. Wienk, S. Sollie, R. Bobbink \& J. T. A. Verhoeven, 2003. Long-term effects of yearly grazing by moulting Greylag gees (Anser anser) on reed (Phragmites australis) growth and nutrients dynamics. Aquatic Botany 75: 229-248.

Van Donk, E., R. D. Gulati, A. Iedema \& J. T. Meulemans, 1993. Macrophyte-related shifts in the nitrogen and phosphorus contents of the different trophic levels in a biomanipulated shallow lake. Hydrobiologia 251: 19-26.

Van Duren, I. C. \& D. M. Pegtel, 2000. Nutrient limitations in wet, drained and rewetted fen meadows: evaluation of methods and results. Plant and Soil 220: 35-47.
Van Geest, G. J., F. C. J. M. Roozen, H. Coops, R. M. M. Roijackers, A. D. Buijse, E. T. H. M. Peeters \& M. Scheffer, 2003. Vegetation abundance in lowland floodplain lakes determined by surface area, age and connectivity. Freshwater Biology 48: 440-454.

Vretare, V., S. E. B. Weisner, J. A. Strand \& W. Granéli, 2001. Phenotypic plasticity in Phragmites australis as a functional response to water depth. Aquatic Botany 69: $127-145$.

Wassen, M. J., H. G. M. Olde Venterink \& E. O. A. M. Deswart, 1995. Nutrient concentrations in mire vegetation as a measure of nutrient limitation in mire ecosystems. Journal of Vegetation Science 6: 5-16.

Watts, C. J., 2000. Seasonal phosphorus release from exposed, re-inundated littoral sediments of two Australian reservoirs. Hydrobiologia 431: 27-39.

Weihe, P. E. \& R. K. Neely, 1997. The effects of shading on composition between purple loosestrife and broad-leaved cattail. Aquatic Botany 59: 127-138.

Weisner, S. B., 1991. Within-lake patterns in depth penetration of emergent vegetation. Freshwater Biology 26: 133-142.

Willby, N. J., I. D. Pulford \& T. H. Flowers, 2001. Tissue nutrient signatures predict herbaceous-wetland community responses to nutrient availability. New Phytologist 152: 463-481.

Zbierska, J., S. Murat-Błażejewska, K. Szoszkiewicz \& A. E. Ławniczak, 2002. The Nutrients Balance in Wielkopolska Agro-Ecosystems with Respect to Water Quality Protection Using the Samica Stęszewska River Watershed as Example (in Polish). Agricultural University Press, Poznan, Poland. 